\title{
Interaction between M-Like Protein and Macrophage Thioredoxin Facilitates Antiphagocytosis for Streptococcus equi ssp. zooepidemicus
}

\author{
Zhe Ma, Hui Zhang, Junxi Zheng, Yue Li, Li Yi, Hongjie Fan*, Chengping Lu \\ College of Veterinary Medicine, Nanjing Agricultural University, Nanjing, China
}

\begin{abstract}
Streptococcus equi ssp. zooepidemicus (S. zooepidemicus, S.z) is one of the common pathogens that can cause septicemia, meningitis, and mammitis in domesticated species. M-like protein (SzP) is an important virulence factor of S. zooepidemicus and contributes to bacterial infection and antiphagocytosis. The interaction between SzP of S. zooepidemicus and porcine thioredoxin (TRX) was identified by the yeast two-hybrid and further confirmed by co-immunoprecipitation. SzP interacted with both reduced and the oxidized forms of TRX without inhibiting TRX activity. Membrane anchored SzP was able to recruit TRX to the surface, which would facilitate the antiphagocytosis of the bacteria. Further experiments revealed that TRX regulated the alternative complement pathway by inhibiting $\mathrm{C} 3$ convertase activity and associating with factor $\mathrm{H}(\mathrm{FH})$. TRX alone inhibited C3 cleavage and C3a production, and the inhibitory effect was additive when FH was also present. TRX inhibited C3 deposition on the bacterial surface when it was recruited by SzP. These new findings indicated that $S$. zooepidemicus used SzP to recruit TRX and regulated the alternative complement pathways to evade the host immune phagocytosis.
\end{abstract}

Citation: Ma Z, Zhang H, Zheng J, Li Y, Yi L, et al. (2012) Interaction between M-Like Protein and Macrophage Thioredoxin Facilitates Antiphagocytosis for Streptococcus equi ssp. zooepidemicus. PLoS ONE 7(2): e32099. doi:10.1371/journal.pone.0032099

Editor: Riccardo Manganelli, University of Padova, Italy

Received November 4, 2011; Accepted January 19, 2012; Published February 27, 2012

Copyright: (C) 2012 Ma et al. This is an open-access article distributed under the terms of the Creative Commons Attribution License, which permits unrestricted use, distribution, and reproduction in any medium, provided the original author and source are credited.

Funding: This study was supported by the Program for New Century Excellent Talents (NCET) at the University of China (NCET-08-0794), the National Transgenic Major Program (2009ZX08009-154B), the Key Technology Program (R65286D), Jiangsu (BE2009388), the Fundamental Research Funds for the Central Universities (KYT 201003), and the Project Funded by the Priority Academic Program Development of Jiangsu Higher Education Institutions. The funders had no role in study design, data collection and analysis, decision to publish, or preparation of the manuscript.

Competing Interests: The authors have declared that no competing interests exist.

*E-mail: fhj@njau.edu.cn

\section{Introduction}

Streptococcus equi ssp. zooepidemicus (S. zooepidemicus, S.z), a member of the Lancifield's group $\mathrm{C}$, is an opportunistic pathogen that could infect a wide variety of non-human species, including important domesticated cattle such as horses, cows, swine, sheep, and dogs. In China, S. zooepidemicus is the major cause of diseases in swine. Occasionally, it can infect humans via zoonotic transmission from the infected animals and cause invasive infections in humans such as septicemia and meningitis. [1,2]. Pathogenic microorganisms in a nonimmune host must evade from the innate immune system before the infection can be established [3]. Many pathogens have unique surface structures that can interfere with the phagocytosis by the neutrophils [4]. The hyaluronic acid capsules expressed by many strains can also hinder the phagocytosis process [5]. M protein is an important virulence factor of group A streptococci: this fibrillar, surface-exposed protein deters opsonization of the organism using the alternate complement pathway [6,7]. Previous studies have demonstrated that $S$. zooepidemicus carry antigens with antiphagocytic characteristics similar to the $\mathrm{M}$ proteins expressed from Lancefield group A and G streptococci; hence it was named M-like protein $(\mathrm{SzP})$ [8]. SzP is a cell surface-anchored protein that confers phagocytosis resistance [9]. SzP-knockout strains had 1000-fold decrease in LD50 compared to the wild type [10]. However, the molecular mechanism by which $\mathrm{SzP}$ protects $S$. zooepidemicus from phagocytosis is poorly understood.
Thioredoxin (TRX) is a small multifunctional protein with a redox-active dithiol/disulfide in the conserved active site. The functions of TRX are to reduce protein disulfide bonds and to scavenge hydrogen peroxide together with peroxiredoxins [11]. It was originally identified as a cytokine-like factor in virustransformed cells [12]. TRX is localized in the cytosol and on the cell surface. The release of TRX in various cells types can be triggered by different extracellular stimuli [13]. Many pathogenic bacteria can evade the complement-mediated host defense by recruiting factor $\mathrm{H}(\mathrm{FH})$ to the bacterial surfaces. [14-16]. $\mathrm{M}$ and M-like proteins show affinity for $\mathrm{FH}$, their interaction is proposed as the mechanism by which $\mathrm{M}$ and M-like proteins exert their antiphagocytic effects $[17,18]$. The C3 convertase activity analysis found that TRX could inhibit the conversion of C3 to C3a and C3b. This suggested that TRX could have a similar function with $\mathrm{FH}$, which was consistent with previous findings [19].

Our studies were focused on the molecular mechanism(s) by which $\mathrm{SzP}$ protects $S$. zooepidemicus from phagocytosis. We identified the SzP/TRX interaction and found that the activity of TRX was not inhibited by this interaction. We also found that TRX could facilitate the antiphagocytic process when it was recruited by SzP anchored on the surface of $S$. zooepidemicus. Further experiments showed that TRX regulated the alternative complement pathway via $\mathrm{C} 3$ convertase inhibition and $\mathrm{FH}$ association. TRX alone could inhibit C3 cleavage and C3a production, and the inhibitory effect was additive with FH. TRX was able to inhibit C3 deposition on the 
bacterial surface when it was recruited by $\mathrm{SzP}$ of $S$. zooepidemicus. To our knowledge, this was the first reported identification of $\mathrm{SzP} /$ TRX interaction. It mediated resistance to the phagocytic activity of macrophages. Our findings could contribute to the general understanding on how $\mathrm{SzP}$ confers phagocytosis resistance.

\section{Results}

\section{S. zooepidemicus M-like protein (SzP) interacts with Thioredoxin}

The coding region of ATCC35246 SzP in S. zooepidemicus was screened against a porcine pulmonary alveolar macrophage (PAM) cDNA library using the Split-ubiquitin yeast two-hybrid $(\mathrm{Y} 2 \mathrm{H})$ technique. In the $\mathrm{Y} 2 \mathrm{H}$ screen, 28 proteins were identified to have a potential interaction with the $\mathrm{SzP}$ protein in the yeast cells growing on $\operatorname{Trp}^{-} \mathrm{Ade}^{-} \mathrm{His}^{-} \mathrm{Leu}^{-} 80 \mathrm{mM}$ aminotriazole media (Sigma). Thioredoxin (TRX, GenBank No. NM_214313.1) was repetitively identified 13 times (Table 1). The fusion plasmids carrying these 28 proteins were isolated after the first round of the screen and retested in fresh yeast cells containing pDHB1-SzP. Only 12 potential $\mathrm{SzP}$ interacting proteins were identified in the retest and they were pursued further. Figure 1A showed the interaction between $\mathrm{SzP}$ and TRX with appropriate controls. A total of 12 candidate $\mathrm{SzP}$ interacting proteins were identified from the retest and their putative functions were listed in Table 1.

The result obtained with the two-hybrid system was confirmed by Co-IP through two independent detection approaches. A ProLabel tag (an enzyme capable of producing a strong chemiluminescent signal via catalyzing its substrate) was genetically integrated at the $\mathrm{N}$-terminal of each of these 12 candidate proteins using the vector pProLabel-C. pProLabel-C or pProLabel-G fused with the candidate protein were then transfected into HEK 293 cells with plasmid pAcGFP1-C, expressing GFP alone, or with plasmid pAcGFP1-SzP, a derivative of pAcGFP1-C coding for a GFP-SzP fusion protein. For the chemiluminescent detection approach, protein $G$ plus/A agarose beads and anti-GFP monoclonal antibodies were incubated with the transfected HEK293 lysate and the luminescence level of the substrate-ProLabel reaction was measured. As seen in Figure 1B, the luminescence signal was only detected when $\mathrm{SzP}$ and TRX were both present, while GFP or ProLabel-tag alone was unable to bind with TRX or SzP. TRX was the only one of these 12 candidate proteins that co-immunoprecipitated with $\mathrm{SzP}$ in vitro. In addition, Western-Blot detection approach was performed. Protein G plus/A agarose beads and anti-TRX antibodies were incubated with the transfected HEK293 lysate and GFP-SzP was detected with the anti-GFP monoclonal antibodies. Figure $1 \mathrm{C}$ was consistent with these results. Altogether, we identified the interaction of SzP/TRX for the first time.

\section{SzP interacts with oxidized and reduced TRX in vitro}

We investigated if the $\mathrm{SzP} / \mathrm{TRX}$ interaction was dependent on oxidized or reduced form of TRX. For this purpose, TRX bound protein $\mathrm{G}$ beads were coated with anti-TRX polyclonal antibodies and treated with $\mathrm{H}_{2} \mathrm{O}_{2}$ before the in vitro binding assay. We found a clear difference of migration in polyacrylamide gels between the $\mathrm{H}_{2} \mathrm{O}_{2}$-treated and the DTT-treated TRX (Figure 2A). This result suggested the efficiency of the oxidative modification by $\mathrm{H}_{2} \mathrm{O}_{2}$, which was consistent with previous findings [20]. However, the oxidative treatment did not noticeably hinder the SzP/TRX interaction. The interaction was still present with reduced TRX in the DTT treated samples (Fig. 2B).

\section{SzP and TRX interaction does not inhibit TRX activity}

The conserved active site of TRX has two cysteines that are essential for its redox activity. Previous report showed that the active site was where some TRX interaction partners bind [21]. We decided to investigate if this site was also necessary for the binding of SzP. TRX-pPR3-N and Mut-Trx-pPR3-N (C32S/C35S), a Cys32 and Cys35 mutant, were transformed into the yeast strain NMY51 containing a bait plasmid SzP-pDHB. The transformed yeast colonies grew on $\mathrm{Trp}^{-} \mathrm{Ade}^{-} \mathrm{His}^{-} \mathrm{Leu}^{-} 80 \mathrm{mM}$ aminotriazole selective media. Both the wild-type and the mutant TRX were able to interact with $\mathrm{SzP}$, suggesting that the integrity of the active site was not necessary for this interaction (Fig. 1D).

Table 1. Candidate SzP interacting proteins and their putative functions.

\begin{tabular}{|c|c|c|}
\hline Interactor & Number of hits & Protein function \\
\hline Thioredoxin & 13 & In our article \\
\hline Glia maturation factor gamma-like & 5 & $\begin{array}{l}\text { Maybe involved in glial differentiation, neural regeneration, and inhibition } \\
\text { of tumor cell proliferation }\end{array}$ \\
\hline Mitochondrial import receptor subunit TOM6 homolog & 3 & $\begin{array}{l}\text { Modulate the assembly and dissociation of the multisubunit preprotein } \\
\text { translocase (Tom) machinery of the mitochondrial outer membrane }\end{array}$ \\
\hline Selenoprotein K & 3 & Boosting the immune function in host defence and inflammatory diseases \\
\hline Protein Sec61 subunit beta-like & 2 & $\begin{array}{l}\text { Proteins enter the ER by the Sec } 61 \text { translocon, a proteinaceous channel } \\
\text { composed of three subunits, alpha, beta and gamma. }\end{array}$ \\
\hline BCL2/adenovirus E1B $19 \mathrm{kDa}$ interacting protein 3-like & 1 & Cause cell death by targeting mitochondria \\
\hline Syntaxin 8 & 1 & Involved in vesicular trafficking and docking \\
\hline Transmembrane protein CD9 & 1 & $\begin{array}{l}\text { Member of the tetraspan transmembrane protein family, which facilitates, } \\
\text { the infection of tissue culture cells with CDV }\end{array}$ \\
\hline Guanine nucleotide binding protein (G protein), gamma 11 & 1 & $\begin{array}{l}\text { G proteins are heterotrimers consisting of } \alpha, \beta, \gamma \text { subunits, involved in } \\
\text { signal transduction }\end{array}$ \\
\hline TRAF3-interacting JNK-activating modulator-like & 1 & $\begin{array}{l}\text { An adapter molecule that specifically regulates TRAF3-mediated JNK } \\
\text { activation }\end{array}$ \\
\hline Mast cell-expressed membrane protein 1-like & 1 & Homologous to human granule membrane protein 17 \\
\hline Clone:AMP010010B04, expressed in alveolar macrophage & 1 & Unknown \\
\hline
\end{tabular}


A

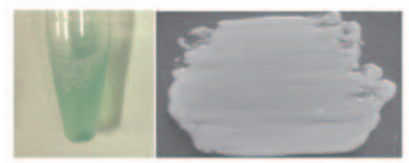

pDHB1-SzP + pPR3-N-TRX

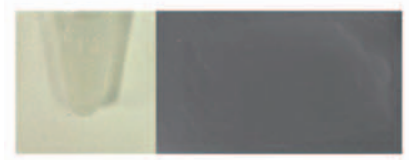

pDHB1 + pPR3-N-TRX

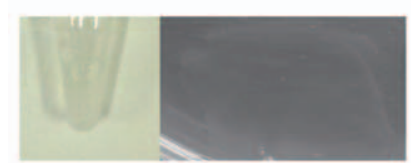

Control-

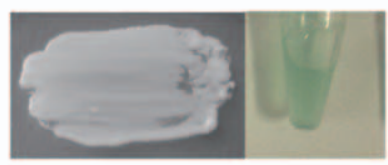

Control+

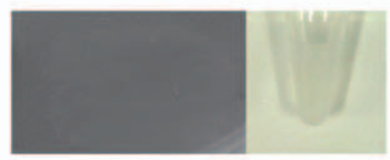

pDHB1-SzP + pPR3-N

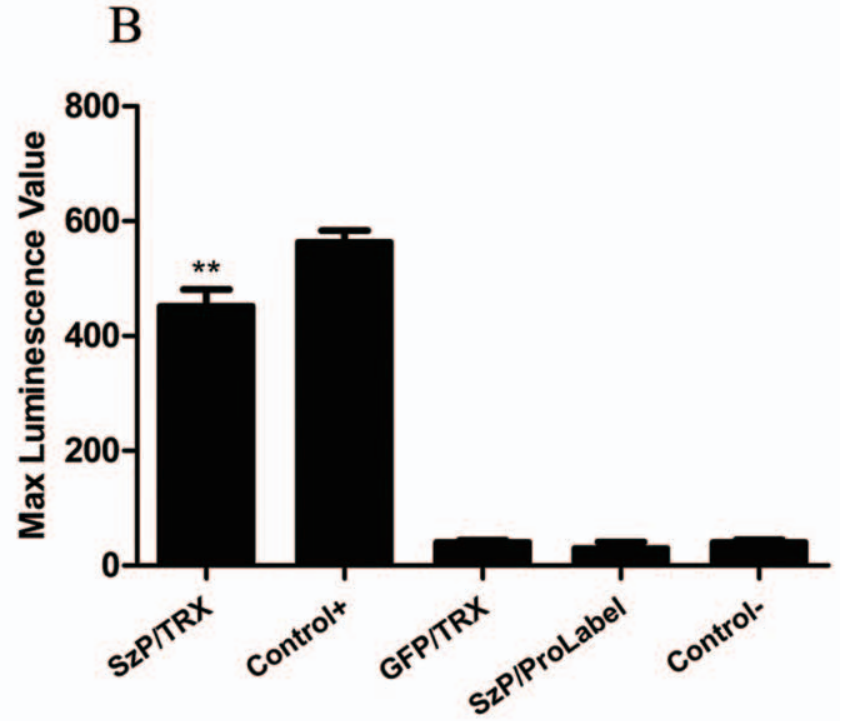

C

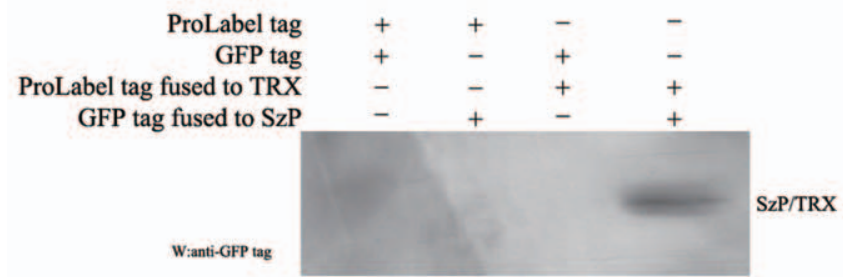

D

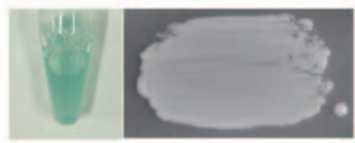

SzP/TRX

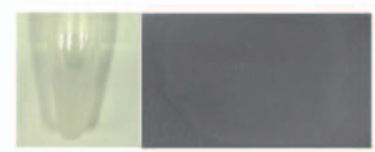

Control-

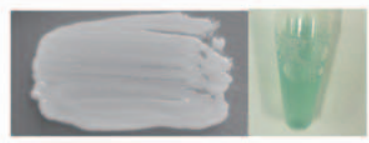

SzP/Mut TRX

Figure 1. The interaction between SzP and TRX. A: The split-ubiquitin yeast two hybrid assay. SzP was cloned in frame into the yeast expression vector (pDHB1), fused at its N-terminus to a small membrane anchor (the yeast ER protein Ost4) and at its C-terminus to a reporter cassette composed of the C-terminal half of ubiquitin (Cub) and a transcription factor (LexA-VP16). The recombinant TRX-pPR3-N (fusion to the mutated Nterminal half of ubiquitin) and SzP-pDHB1 were co-transformed into the NMY51 yeast strain. The co-transformed cells were selected on Trp-/Ade-/ His-/Leu- 80 mM Aminotriazole dropout plates. The control+ represented co-transformation of pDSL-Delta-p53 and pDHB1-largeT (Dualsystems Biotech, Switzerland). Tubes showed the results of Liquid $\beta$-galactosidase assay. B: Luminescence value of the substrate corresponding to the pProLabel tag fused to TRX. Histogram showed max luminescence value through $1 \mathrm{~h}$ monitoring $(\mathrm{n}=3, \mathrm{mean} \pm \mathrm{SD}$, ** indicates that a value was significantly different $(\mathrm{p}<0.01)$ from the control- group). C: SzP was immunoprecipitated from HEK293 cells expressing TRX. HEK293 lysates were immunoprecipitated with rabbit polyclonal antibodies against TRX. The immunoprecipitates were subjected to the western blotting analysis with GFP monoclonal antibodies against GFP -SzP. D: pDHB1-SzP and pPR3-N-mut-TRX were co-transformed into the yeast strain NMY51. SzP interacted with mutant TRX, which had mutations $\mathrm{Cys}^{32}$ and $\mathrm{Cys}^{35}$ to Ser (C32S/C35S) in its active site. Tubes showed the results of Liquid $\beta-$ galactosidase assay. doi:10.1371/journal.pone.0032099.g001

To investigate whether the SzP/TRX interaction could inhibit TRX activity, we used an in vitro insulin reduction assay to measure the reducing activity of TRX. Our results showed that high concentration of SzP did not inhibit TRX activity (Fig. 2C). The SzP/TRX interaction did not inhibit TRX activity and rendered TRX more prone to the complement pathway regulation and other biological functions.

\section{S. zooepidemicus recruits TRX to the surface and facilitates antiphagocytosis}

We further determined that TRX interacted with $\mathrm{SzP}$ of viable S. zooepidemicus. S. zooepidemicus wild strain and the SzP-knockout strain were both incubated with TRX. PBS was used as a negative control. After suitable treatment, all 3 samples were analyzed using flow cytometry. We found that the $S$. zooepidemicus wild type, but not the SzP-knockout strain, was able to recruit TRX to its surface (Fig. 3). This suggested that the surface anchored $\mathrm{SzP}$ was important for TRX recruitment.

The recruitment of TRX to the cell surface of $S$. zooepidemicus's suggested that this interaction could enhance the bacterial adaptation in hosts, thus contribute to the antiphagocytosis of $S$. zooepidemicus. We investigated this issue by assessing the effect of the $\mathrm{SzP} / \mathrm{TRX}$ interaction on the phagocytosis in vitro. We employed RNA interference to knock down endogenous TRX expression in the macrophages. Using RT-PGR, we found that the level of TRX mRNA was reduced to less than $15 \%$ in macrophages treated with 
A

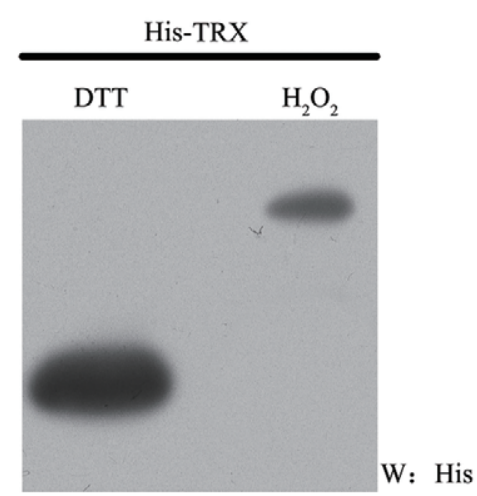

B

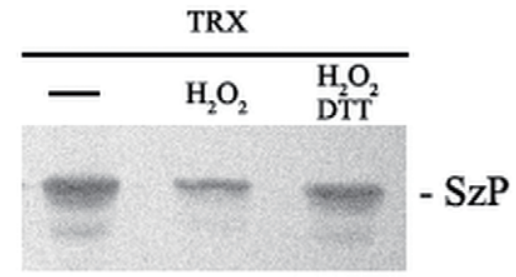

$\mathrm{C}$

In Vitro

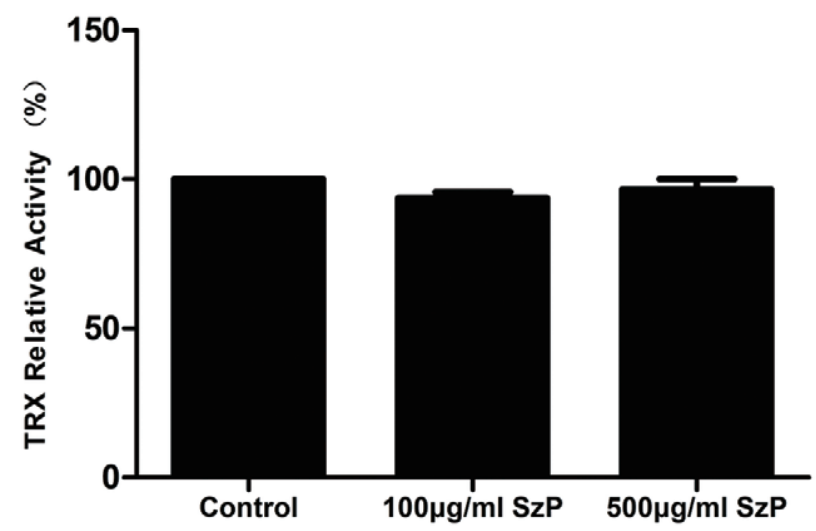

Figure 2. Oxidized and reduced forms of TRX can interact with SzP. A: TRX bound to protein $\mathrm{G}$ beads was treated with either $1 \mathrm{mM} \mathrm{H}_{2} \mathrm{O}_{2}$ or $100 \mathrm{mM} \mathrm{DTT}$ for $15 \mathrm{~min}$ at room temperature. The proteins were separated by native PAGE and visualized by the western blot analysis for His-tag fused TRX. B: Oxidized and reduced forms of TRX were able to interact with SzP. His-TRX bound to protein G beads were incubated with Nonidet P-40 buffer or with buffer supplemented with $1 \mathrm{mM} \mathrm{H}_{2} \mathrm{O}_{2}$ for $15 \mathrm{~min}$ at room temperature. After extensive washing in the same buffer, the proteins were submitted to the binding assay. As a control to revert oxidation, a part of the $\mathrm{H}_{2} \mathrm{O}_{2}$-treated fusion protein was incubated with buffer containing $100 \mathrm{mM}$ DTT for $15 \mathrm{~min}$ prior to SzP incubation. C: SzP did not inhibit TRX activity. The insulin disulfide reduction assay was performed in the lysates obtained from confluent cultures described under "Materials and Methods." The activity of TRX bound to SzP in vitro: TRX activity was detected after incubating $10 \mu \mathrm{g}$ TRX with $100 \mu \mathrm{g} / \mathrm{ml}$ or $500 \mu \mathrm{g} / \mathrm{ml} \mathrm{SzP}$ at $37^{\circ} \mathrm{C}$ for $2 \mathrm{~h}$. Control samples were treated with PBS. $(n=3$, mean \pm SD). doi:10.1371/journal.pone.0032099.g002

RNAi than the nt-RNAi control cells (Fig. 4A). We also detected a significant decrease in TRX protein level in RNAi treated cells then the nt-RNAi control cells (Fig. 4B, top panel). The level of $\beta$ actin in macrophages was used as an internal control (Fig. 4B, bottom panel).

S. zooepidemicus wild strain and SzP-knockout strain were tested in an in vitro phagocytosis assay Briefly, mouse macrophages with or without mouse serum were treated with the wild strain and TRXi strain cells. The ingestion of SzP-knockout strain in the wild and TRXi Raw264.7 cells suggested that the phagocytosis of the macrophages was not inhibited by the TRX interference. Serum was used as a source of the complement system. It had an opsonophagocytosis effect which allowed the macrophages to ingest bacteria more efficiently. Our result suggested that TRX could hinder the opsonophagocytosis process, as S. zooepidemicus containing surface TRX was less ingested by macrophages than the SzP knock-out strain or the non-TRX treated S. zooepidemicus. However, the phagocytosis was not affected by TRX in the absence of the serum. SzP facilitated S. zooepidemicus to avoid phagocytosis with or without the serum. All these results indicated that TRX could hinder phagocytosis when it was recruited by $\mathrm{SzP}$ on the bacterial surface in the presence of the serum. On the other hand, $\mathrm{SzP}$ was able to elicit antiphagocytosis responses through another mechanism in the absence of the serum (Fig. 5).

\section{The complement pathway regulation}

We used the immunoblotting analysis to demonstrate that $\mathrm{FH}$ interacted with SzP, TRX and SzP/TRX complex. Previous report found that TRX interacted strongly with $\mathrm{FH}$ [19]. We found that $\mathrm{SzP}$ of $S$. zooepidemicus had affinity with $\mathrm{FH}$ as well. We also found that the SzP/TRX complex, visualized by the band above SzP and TRX, was able to bind with FH (Fig. 6A).

The effect of TRX, FH and $\mathrm{SzP}$ on the activity of C3 convertase in the alternative complement pathway was determined using the fluid phase assay. Next, we examined the effect of TRX on FH, a major regulator of the alternative complement pathway and an 

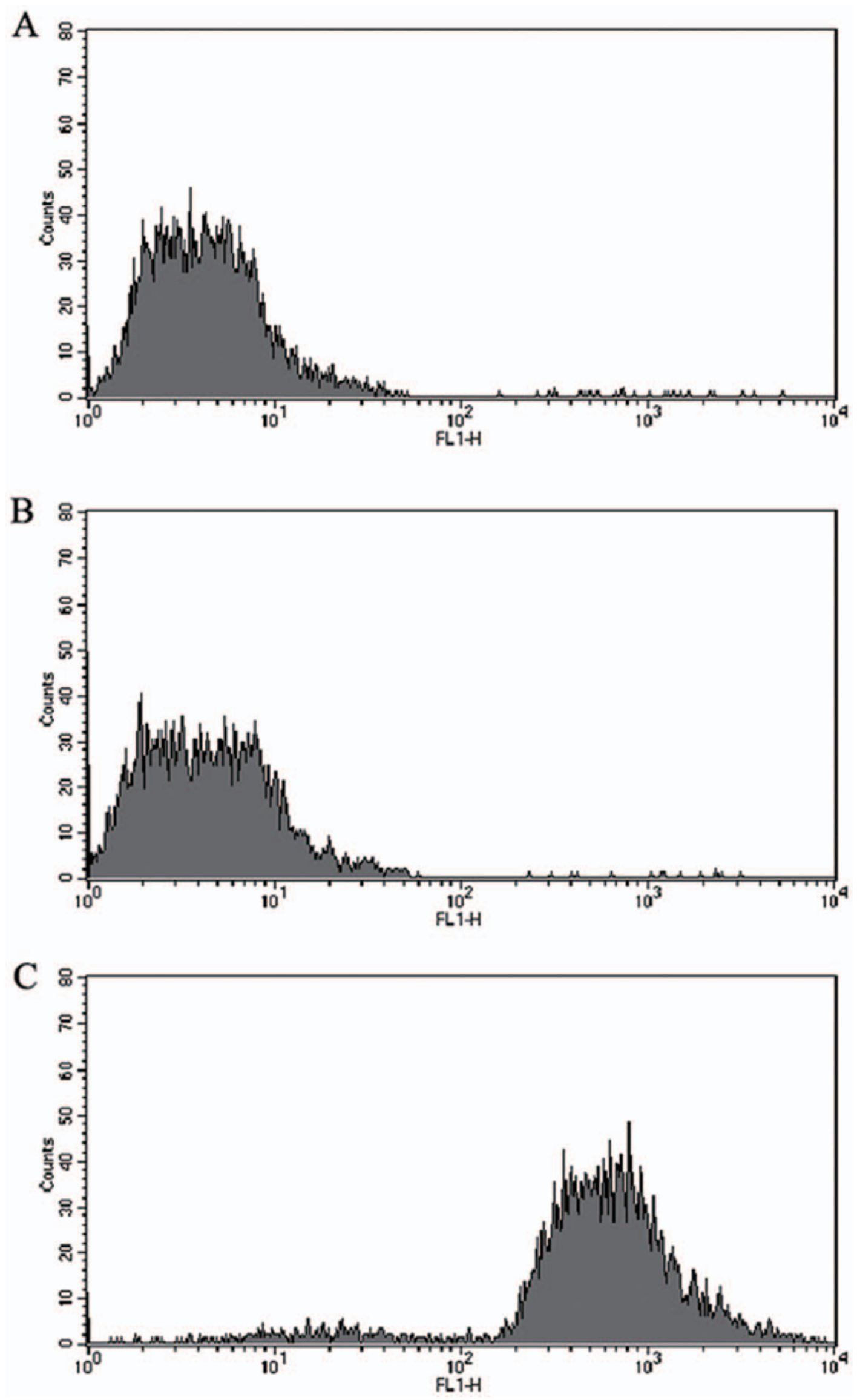
Figure 3. Recruitment of TRX to the surface of viable $S$. zooepidemicus. Flow cytometry results showed that TRX could bind to the surface SzP of S. zooepidemicus. A: S. zooepidemicus wild strain incubated with PBS (negative control); B: SzP-knockout strain incubated with TRX; C: S. zooepidemicus wild strain incubated with TRX. The SzP of S. zooepidemicus interacted with TRX and recruited TRX to the bacterial surface. doi:10.1371/journal.pone.0032099.g003

inhibitor of the G3 conversion to C3a and C3b. Using the fluidphase technique, the production of C3a from C3 conversion was detected by adding factor $\mathrm{B}$ and factor $\mathrm{D}$ (Fig. 6B). We found that TRX alone inhibited C3 cleavage. Furthermore, we found that the inhibitory effect was additive with $\mathrm{FH}$, as $5 \mu \mathrm{g}$ TRX and $5 \mu \mathrm{g} \mathrm{FH}$ together had a stronger inhibition on the activity of C3 convertase than $10 \mu \mathrm{g}$ TRX or $10 \mu \mathrm{g}$ FH alone. SzP alone did not show any effect on C3 cleavage. These results indicated that $\mathrm{SzP}$ could recruit TRX as a regulator of the alternative complement pathway and the regulation of TRX could also be distinct from the regulation of $\mathrm{FH}$.

Phagocytes can recognize foreign particles most efficiently after opsonization with serum-derived opsonins such as IgG and C3b or inactive C3b. Studies using C3 antibodies (anti-C3) showed that TRX and FH both prevented C3b deposition on the $S$. zooepidemicus wild strain (Fig. 6C, 6D). We detected more C3b deposition on the cell surface of SzP-knockout strain compared to the $S$. zooepidemicus wild strain after treatment with TRX and FH. Immunoblotting with C3 specific antiserum revealed that the level of surface localized $\mathrm{C} 3 \mathrm{~b}$ and $\mathrm{iC} 3 \mathrm{~b}$, the major derivatives of $\mathrm{C} 3$, was reduced after TRX or FH treatment in the presence of $\mathrm{SzP}$. The antiphagocytic effectiveness of the TRX was dose-dependent, but when bacteria was saturated by TRX, the antiphagocytosis stopped increasing. (Fig. 6E)

\section{Discussion}

There are generally cross-talks between bacteria and the host immune system. S. zooepidemicus has developed a multitude of strategies to evade host defenses by interfering many aspects of the immune system. Such interference can normally lead to the downregulation or inhibition of the inflammatory responses. Previous studies have indicated that $\mathrm{SzP}$ in $S$. zooepidemicus shares similar antiphagocytic characteristics with the $\mathrm{M}$ proteins in the Lancefield groups $\mathrm{A}$ and $\mathrm{G}$ streptococci [22]. SzP of $S$. zooepidemicus is a $40.1-\mathrm{kD}$ surface-anchored protein that elicits serum opsonic and protective responses in mice and horses [9]. We cloned SzP gene of $S$. zooepidemicus ATCC35246 and investigated the mechanism by which they conferred antiphagocytic effects against the host immune responses.

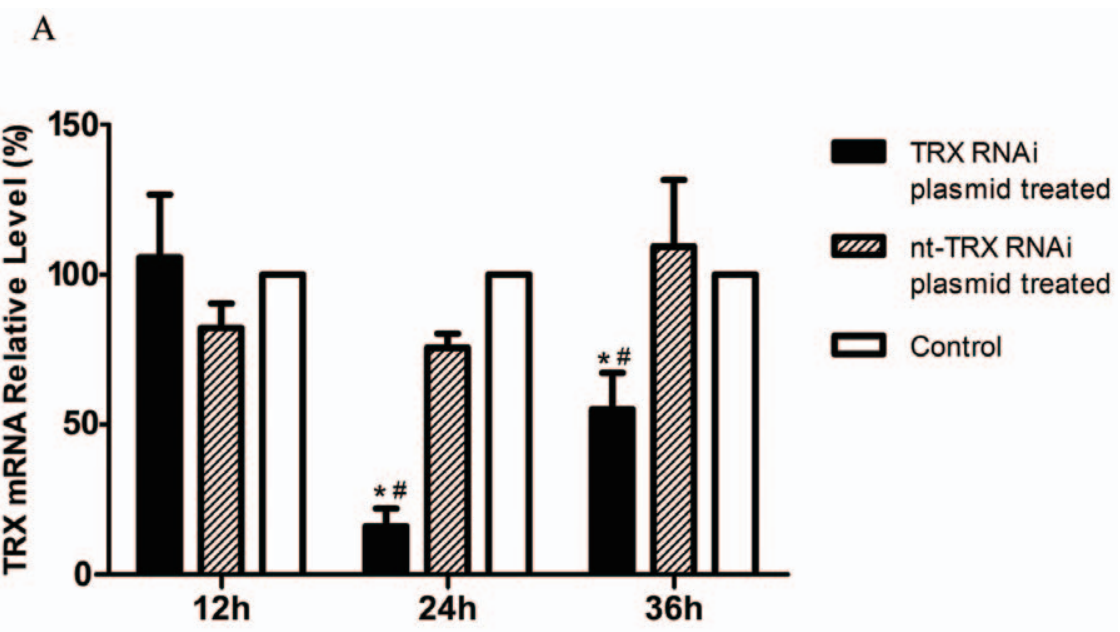

B

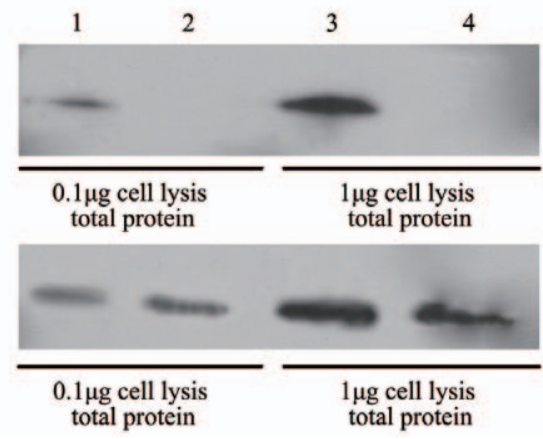

TRX

$\beta$-actin

Figure 4. TRX knockdown. A: The relative level of TRX mRNA was detected by RT-PCR. $\beta$-actin was used as the reference control. The mRNA level of control was considered as $100 \%$. The relative level of TRX mRNA was calculated using equation $2^{-\Delta \Delta C T}\left(n=3\right.$, mean $\pm S D$, the symbols, ${ }^{*}$ and \#, indicate that a value differed significantly $(p<0.05)$ from the control and nt-TRX RNAi treated groups, respectively.); B: Reduction in TRX protein levels was confirmed by the western blot analysis in Raw264.7 cell. Lane 1 and 3 were nt-TRX RNAi plasmid treated cell lysis, lane 2 and 4 were TRX RNAi plasmid treated cell lysis. All samples were extracted at $24 \mathrm{~h}$ after transfection. doi:10.1371/journal.pone.0032099.g004 


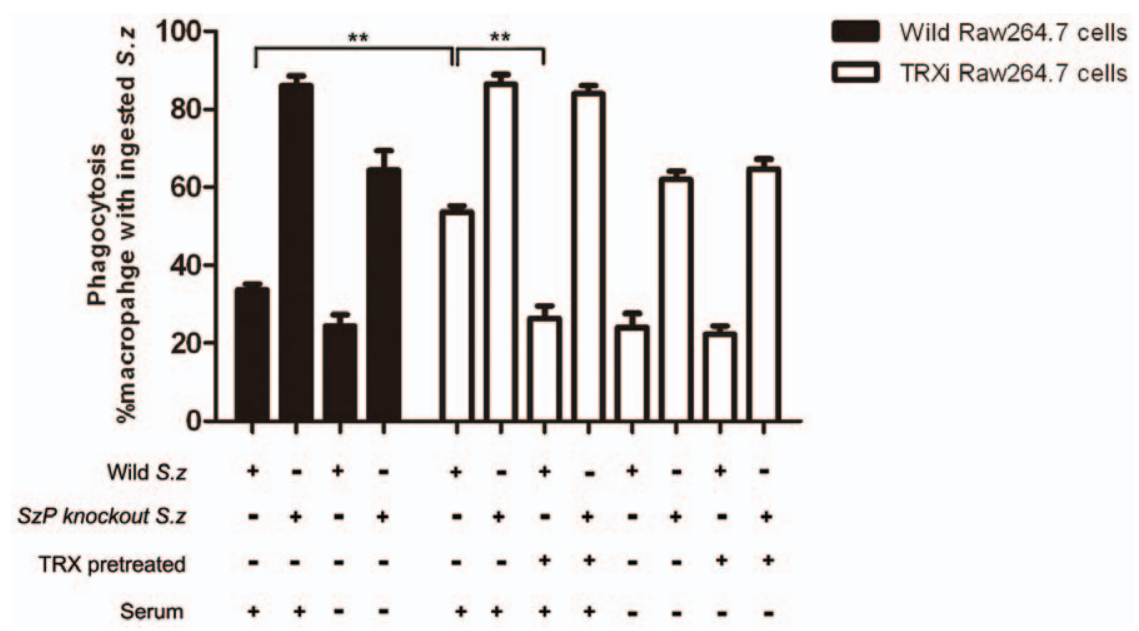

Figure 5. The SzP/TRX interaction facilitated S. zooepidemicus to avoid being phagocytized. The phagocytosis percentage of Raw264.7 wild strain and TRXi strain did not differ significantly. The S. zooepidemicus SzP-knockout strain were phagocytized effectually. In the presence of the serum, the antiphagocytosis of S. zooepidemicus was more pronounced with the SzP/TRX interaction, as there was significantly more macrophage containing ingested S. zooepidemicus in TRXi Raw264.7 cells than the wild type Raw264.7 cells. Thus, the SzP/TRX interaction reduced the phagocytosis of $S$. zooepidemicus by the macrophages in the host immune system. The phagocytosis percentage of the TRX pretreated $S$. zooepidemicus wild strain was significantly lower than the SzP-knockout strain in the TRXi Raw264.7 cells. In the absence of the serum, the phagocytosis of the macrophages was independent of TRX, and only SzP was able affect phagocytosis $(n=3$, mean $\pm S D, * * p<0.01)$. doi:10.1371/journal.pone.0032099.g005

Initial attempt to identify $\mathrm{SzP}$ interaction partners using the classical yeast two-hybrid system was not successful. Classical $\mathrm{Y} 2 \mathrm{H}$ requires both proteins to interact in the nucleus and the nuclear environment may cause certain proteins to fold improperly and thus abolish their interactions with other proteins [23]. Next, we used the split-ubiquitin yeast two-hybrid system to detect $\mathrm{SzP}$ interaction partners. This system does not require protein interactions to occur in the nucleus and is therefore ideal for cytosolic proteins as well as membrane proteins. The C-terminal of $\mathrm{SzP}$ is anchored to the membrane while the rest of the protein is highly hydrophilic. We conjectured that the SzP/TRX interaction occurred at the cytosolic side of the plasma membrane.

The current study identified the interaction between $\mathrm{SzP}_{\mathrm{P}}$ and TRX. We further provided three lines of evidence to verify that $\mathrm{SzP}$ was associated with TRX; (i) An interaction between $\mathrm{SzP}$ and TRX was screened and confirmed in the split-ubiquitin yeast twohybrid system. (ii) $\mathrm{SzP}$ and TRX were co-immunoprecipitated from pAcGFP1-SzP and pProLabel-TRX transfected HEK293 cells, and the result was detected with ProLabel-tag enzyme activity and confirmed with western-blot. (iii) $\mathrm{FH}$ was able to bind with SzP and TRX, as well as the SzP/TRX complex. This suggested that the binding of $\mathrm{SzP}$ to $\mathrm{TRX}$ was biologically relevant.

TRX plays a variety of redox-related roles that are conserved from $E$. coli to humans. It is a small, ubiquitous, multifunctional protein that contains a redox-active disulfide/dithiol within its active site, -Cys-Gly-Pro-Cys- [20]. TRX mutants with Cys32/ Cys35 to Ser mutations were still able to interact with SzP (Fig. 1D). Furthermore, both oxidized and reduced forms of TRX were able to interact with $\mathrm{SzP}$ (Fig. 2B). This suggested that the redox active site was not the site of $\mathrm{SzP} / \mathrm{TRX}$ interaction. It was found that oxidization leads to TRX dimerization through a disulfide bond between Cys73 in both monomers [24,25]. Therefore, the residues necessary for $\mathrm{SzP}$ interaction were not hindered in the dimeric form of TRX. It was interesting to note that the activity of TRX was not inhibited by $\mathrm{SzP}$ in vitro. These results could explain why $\mathrm{SzP} / \mathrm{TRX}$ interaction did not inhibit TRX activity.
To better understand how surface protein SzP could contribute to the pathogenecity of $S$. zooepidemicus, we investigated the interaction of $S$. zooepidemicus with Raw264.7 cells, using the wild strain ATCG35246 (which is virulent to mice) and SzP-knockout strain attenuated in virulence. We employed flow cytometry to detect the recruitment of TRX to the surface of viable $S$. zooepidemicus. This recruitment was mediated by $\mathrm{SzP}$, since $\mathrm{SzP}-$ knockout strain was unable to recruit TRX to the surface. We also found that both the $S$. zooepidemicus wild type and the SzP-knockout strain were efficiently phagocytized by macrophages when TRX was absent, though the wild strain was harder to be ingested than the SzP-knockout strain. We believed that there should be another mechanism of $\mathrm{SzP}$ to elicit antiphagocytosis responses in $S$. zooepidemicus. The current work provided evidence that the $S$. zooepidemicus wild strain could avoid being phagocytized much more effectively, whereas the mutant strains were rapidly ingested by Raw264.7 cells even in the presence of TRX. All these results were obtained in the presence of the serum. However, TRX could not facilitate antiphagocytosis responses in the absence of the serum, it was only related to SzP. These results indicated the expression of $\mathrm{SzP}$ allowed the bacteria to recruit TRX, which had effects on the complement pathway. Therefore, the SzP/TRX interaction facilitated the antiphgocytic response of the $S$. zooepidemicus

Previous report found that the wild-type $S$. pyogenes expressing M protein and/or M-like proteins on the cell surface could survive inside the neutrophils [18]. S. pyogenes mutant strains that lacked either $\mathrm{M}$ protein and/or M-like proteins were rapidly killed. M and M-like proteins display affinity for several human plasma proteins such as IgG [26], C4 BP [27], fibrinogen [28] and $\mathrm{FH}$ [29]. It may be possible that these interactions could interfere with normal host immune mechanisms, including phagocytosis. We believed that $\mathrm{SzP}$ in $S$. zooepidemicus elicit antiphagocytosis through its interaction with TRX.

FH can inhibit the conversion of $\mathrm{C} 3$ to $\mathrm{C} 3 \mathrm{a}$ and $\mathrm{C} 3 \mathrm{~b}$ and inactivate C3b. It is recognized as the main regulator of C3 convertase. Many pathogenic organisms evade phagocytosis by coating their surface with the host FH [30]. We asked if $S$. 
A

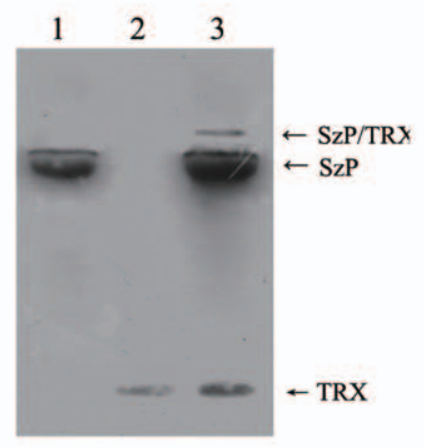

B

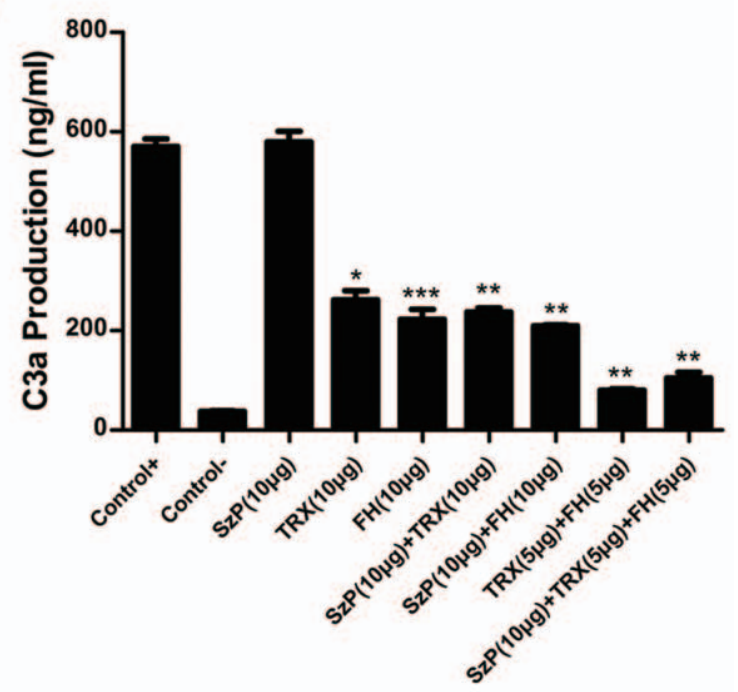

$\mathrm{C}$

D

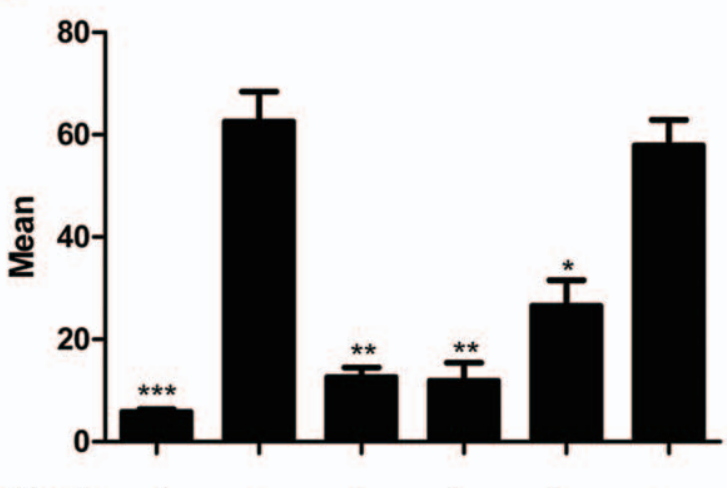

S. $z$ wild strains

P-knockout strains

TRX treated

FH treated

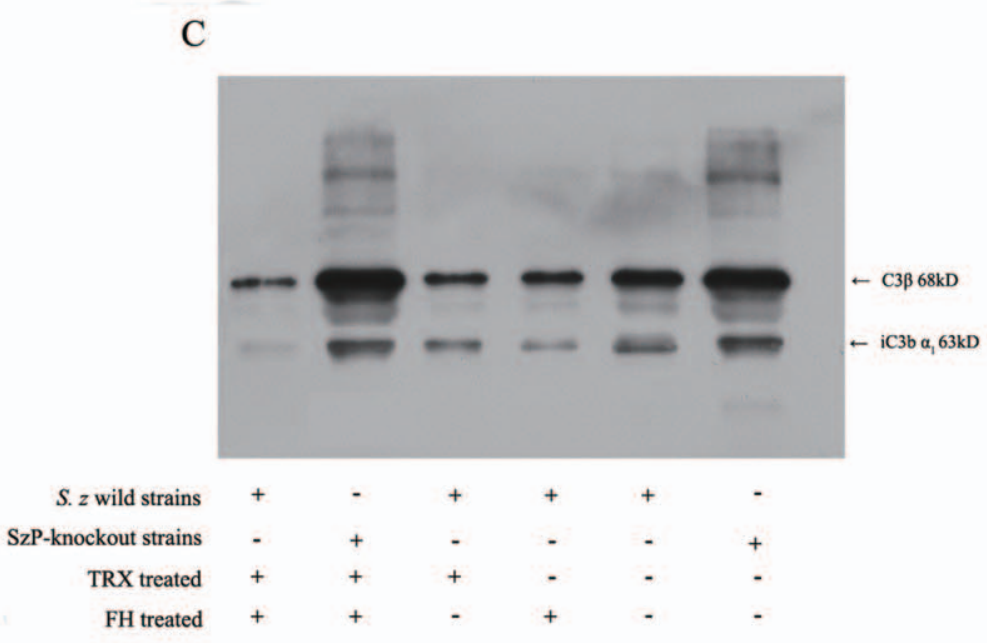

Figure 6. SzP/TRX interaction contributed to the FH recruitment and reduced the $\mathrm{C} 3$ deposition on the bacterial surface, beneficial for S. zooepidemicus to evade phagocytosis of the host immune system. A: The binding of FH to SzP (lane 1), TRX (lane 2) and the SzP/TRX complex (Lane 3) was demonstrated by using polyclonal goat antiserum to $\mathrm{FH}$ in an immunoblot analysis. B: TRX inhibited C3 convertase activity in the fluid phase. Fluid phase alternative pathway $\mathrm{C} 3$ convertase was generated by the addition of purified $\mathrm{C} 3, \mathrm{C} 3 \mathrm{i}$, factor $\mathrm{B}$, and $0.1 \mathrm{M} \mathrm{MgCl} 2.10 \mu \mathrm{g}$ of 
TRX or FH were added followed by the addition of factor D to a final volume of $125 \mu$. Purified components only (control+); purified complement components without factor D (control-). The inhibition of C 3 convertase was determined by C3a generation after 30 min of incubation and measured by a C3a ELISA. The effect of dosage increase of FH and TRX on C3a generation $(\mathrm{ng} / \mathrm{ml})$ was shown here. Reduction in C3a generation was correlated with the decreased C3 convertase activity. (Symbol * indicates that a value significantly differs from the control+ group). C: Immunoblot showing C3 components eluted from the surface of the S. zooepidemicus wild strains and the SzP knockout strains following treatment of TRX, FH or TRX and FH in porcine plasma. The blot was developed with the affinity purified antiserum to C3. C3 components eluted from the S. zooepidemicus wild strains and the SzP knockout strains after incubation in porcine plasma were used as the negative control. D: Flow cytometry analysis of S. zooepidemicus surface-bound C3b, a total of 10,000 events were collected per sample and a single gate was used to exclude debris. E: Flow cytometry analysis of gradient concentration TRX pretreated S. zooepidemicus surface-bound C3b. The antiphagocytic effectiveness of the TRX was dose-dependent until saturation. These results were the mean \pm SD for $n=3$, ${ }^{*} p<0.05$, ${ }^{* *} p<0.01,{ }^{* * *} p<0.001$.

doi:10.1371/journal.pone.0032099.g006

zooepidemicus could evade phagocytosis by a similar method via $\mathrm{SzP} / \mathrm{TRX}$ interaction. Our results showed that SzP, TRX and SzP/TRX complex were able to bind with FH. This suggested that the $\mathrm{SzP} / \mathrm{TRX}$ interaction did not prohibit $S$. zooepidemicus to recruit $\mathrm{FH}$ on its surface. We reasoned that although $\mathrm{SzP}_{\mathrm{P}}$ itself could recruit $\mathrm{FH}$ to the cell surface, $\mathrm{SzP} / \mathrm{TRX}$ interaction was still important because TRX could act as a regulator of the alternative complement pathway not only in association with $\mathrm{FH}$ but also on its own. TRX acted additively to $\mathrm{FH}$ in the alternative complement pathway. The increased level of the capsules may enhance phagocytosis resistance, but could also reduce adhesion to the mucosal surface $[31,32]$. has less hyaluronic acid than S. equi. Therefore, S. zooepidemicus has stronger adhesiveness but lower level of capsules, which rendered it more susceptible to phagocytosis [33]. Having an effective antiphagocytosis mechanism is therefore essential to $S$. zooepidemicus. Recruiting $\mathrm{FH}$ via $\mathrm{SzP}$ and TRX to its cell surface would certainly contribute to phagocytosis evasion. When FH was not abundant, S. zooepidemicus could use TRX as succedaneum of FH. C3 deposition experiments showed that TRX and FH both prevented deposition of C3b on $S$. zooepidemicus, which was pretreated with both TRX and FH limited deposition of opsonic C3b on the bacterial surface. This indicated that the $\mathrm{SzP} / \mathrm{TRX}$ interaction contributed to the antiphagocytosis response in $S$. zooepidemicus via the inhibition of the $\mathrm{C} 3 \mathrm{~b}$ deposition.

In conclusion, the SzP/TRX interaction was a novel antiphagocytic mechanism of $S$. zooepidemicus. The SzP/TRX interaction did not influence the TRX activity and function. It also contributed to the $\mathrm{FH}$ recruitment and reduced the C3 deposition on the bacterial surface, allowing $S$. zooepidemicus to be more evasive to the alternative complement pathways. These mechanisms were very beneficial for $S$. zooepidemicus to evade phagocytosis of the host immune system. Additional studies of this interaction will undoubtedly help us to understand better how $\mathrm{SzP}$ is involved in the antiphagocytosis mechanisms.

\section{Materials and Methods}

\section{Ethics}

Porcine PAM was obtained with consent from one healthy pig under the ethical approval granted by the Nanjing Agricultural University Veterinary College. The protocol was approved by the Science and Technology Agency of Jiangsu Province. The approval ID is SYXK (SU) 2010-0005. All efforts were made to minimize animal's suffering.

\section{Cell culture, bacterial strains and transfection conditions}

Raw264.7 cells (ATCG) and HEK 293 cells (ATCG) were maintained in the Dulbecco's modified Eagle medium (DMEM) high glucose (Gibco, Invitrogen Corp., Carlsbad, CA) supplemented with $10 \%$ fetal bovine serum (FBS). Cells were used from passages 5-20.

The $S$. Zooepidemicus wild type strain ATCC35246 and the $S$. zooepidemicus SzP-knockout strain was constructed by our lab [10].
Escherichia coli strains DH5 $\alpha, \mathrm{DH} 10 \mathrm{~B}$ and BL21, Saccharomyces cerevisiae strain NMY51 (MATa his3 $\Delta 200$ trp1-901 leu2-3,112 ade2 LYS2::(lexAop) ${ }_{4}$-HIS3 ura3::(lexAop) ${ }_{8}$-lacZ ade2::(lexAop) ${ }_{8}$ ADE2 GAL4) were used in this study. S. zooepidemicus was cultured with fresh Todd-Hewitt broth (THB) medium. E.coli was cultured with fresh Luria-Bertani (LB) medium. S. cerevisiae was cultured with fresh Yeast Extract Peptone Dextrose Adenine hemisulfate (YPDA) medium.

Raw264.7 cells and HEK 293 cells were transiently transfected using Lipofectamine 2000 and opti-MEM (Invitrogen Corp., Carlsbad, CA) according to the manufacturer's instruction. Media were changed $6 \mathrm{~h}$ post transfection and the cells were treated or assayed $24 \mathrm{~h}$ post transfection. S. cerevisiae was transformed using the LiAc method [34]. Lysates were subject to Western-blot analysis to confirm the expression of the bait gene in the $\mathrm{pDHB} 1$ plasmid.

\section{Split-ubiquitin yeast two-hybrid assay}

We used the Split-ubiquitin yeast two-hybrid DUALhunter system (Dualsystems Biotech, Switzerland) to identify SzP interaction partners from the porcine macrophages [35,36]. The coding region of $S$. zooepidemicus ATCG35246 SzP (GenBank No. EU624402.1), excluding the signal sequence, was amplified by PCR using primers 5' - GCGGGACGGCGATTACGGCGGTTGAGTCAGCTAAGCGTGTA - $3^{\prime}$ (SfiI) and 5'- GCAGCGGGGGCGAGGCGGCGTTTTCTTTGGGTCTTGTTGAC - $3^{\prime}$ (SfiI). PCR product was then inserted into the Split-ubiquitin yeast two-hybrid Cub domain vector $\mathrm{PDHB} 1$ to generate the 'bait' plasmid pDHB1-SzP, which was verified by DNA sequencing. The expression of the bait protein was confirmed. pDHB1-SzP was used to screen a porcine PAM cDNA library (constructed by our lab) for identifying SzP interacting proteins. Positive yeast clones containing the library plasmid encoding Szp interacting proteins were purified and retested for their growth phenotypes. Plasmid DNA preparations for these yeast clones were generated by the Yeast Plasmid Extraction Kit (Biomega). The insert fragment of these prey plasmids was detected by PCR amplification using primers pPR3NF (5' - GTCGAAAATTCAAGACAAGG - $\left.{ }^{\prime}\right)$ and pPR3N -R (5'AGCGTGACATAACTAATTAC - 3'). The chosen prey plasmids were amplified in $\mathrm{DH} 5 \alpha$, recovered through ampicillin selection and identified by DNA sequencing with pPR3N-F primer. The cDNA sequences were used to search GenBank and NCBI BLAST against the porcine genome. After banishing duplication, the remaining plasmids were re-transformed into the yeast cells containing $\mathrm{pDHB} 1-$ SzP. Liquid $\beta$-galactosidase assay was used to retest for their interaction with $\mathrm{SzP}$ in the yeast again.

\section{Co-Immunoprecipitation assay}

GFP was fused at the N-terminal of $\mathrm{SzP}$ in the $S$. zooepidemicus strain ATCC35246 using the vector pAcGFP1-C (Clontech, TAKARA Bio, USA). ProLabel tag was fuse at the N-terminal of 12 porcine candidate proteins using the vector pProLabel-C (Clontech). These 12 plasmids were each co-transfected with 
pAcGFP1-SzP into HEK 293 cells and cultured on $100 \mathrm{~mm}$ plates. Cells were harvested after $36 \mathrm{~h}$ incubation and lysed with the lysis buffer containing $20 \mathrm{mM}$ Tris, $200 \mathrm{mM} \mathrm{NaCl}, 1 \mathrm{mM}$ EDTA, 0.5 NP-40 and Protease inhibitor Cocktail (Pierce, USA) and $1 \times$ PMSF (Sigma, USA). Cell lysates were incubated $2 \mathrm{~h}$ with anti-GFP monoclonal antibody (Beyotime) at $4{ }^{\circ} \mathrm{C}$. Next, $30 \mu \mathrm{l}$ of protein $\mathrm{G}$ plus/A agarose beads (Clontech) was added and incubated at $4^{\circ} \mathrm{C}$ overnight. Next day, the beads were washed five times with the lysis buffer and the activity of ProLabel was measured using the ProLabel Detection Kit II (Clontech). pAcGFP1-p53 and pProLabel-T were used as the positive control, while pAcGFPl-Lam and pProLabel-T (Clontech) were used as the negative control.

After the initial identification of the Szp/TRX interaction, it was again confirmed with Co-IP and western-blot. Protein G plus/ A agarose beads together with anti-mouse TRX polyclonal antibodies (Proteintech, USA) were incubated with HEK293 cell lysates. The samples were washed extensively in the lysis buffer. The beads were boiled in the sample buffer, and the supernatants were loaded onto SDS-PAGE gels. To confirm the SzP/TRX interaction, western-blot against GFP-SzP was performed using anti-GFP monoclonal antibodies.

\section{Reducing/Oxidizing Reagent Treatment}

Oxidization treatment for TRX was performed following a previously publish protocol [37]. Briefly, protein G beads coated with anti-TRX polyclonal antibodies were bound to TRX and treated with $1 \mathrm{mM} \mathrm{H}_{2} \mathrm{O}_{2}$ in Nonidet P-40 buffer for 15 min and then washed 6 times with the buffer prior to $\mathrm{SzP}_{\mathrm{P}}$ incubation. As a control to revert oxidation, a part of the $\mathrm{H}_{2} \mathrm{O}_{2}$-treated fusion protein was incubated with buffer containing $100 \mathrm{mM}$ DTT for 15 min prior to $\mathrm{SzP}$ incubation. After $2 \mathrm{~h}$ incubation, samples were centrifuged and washed five times with Nonidet P-40 buffer. The precipitated proteins were subjected to SDS-polyacrylamide gel electrophoresis and detected by western-blot using anti-SzP monoclonal antibodies [38].

\section{Mutagenesis and TRX activity assay}

We used "QuikChange II Site-directed Mutagenesis Kit" to construct $\mathrm{Cys}^{32}$ and $\mathrm{Cys}^{35}$ to $\mathrm{Ser}(\mathrm{C} 32 \mathrm{~S} / \mathrm{C} 35 \mathrm{~S})$ double mutations in TRX using the TRX-pPR3-N vector as the template (Stratagene). Primers were 5' CTCAGCGACGTGGTCTGGGCGTTCGAAAATGATCAAGCG $3^{\prime}$ and 5' GGCTTGATCATTTTGGAAGGCGCAGACGACGTGGCTGAG $3^{\prime}$. The mutant plasmid was named mut-TRX-pPR3-N, and transformed into the yeast strain containing SzP-pDHB1 plasmid to detect the interaction between SzP and mutant TRX.

TRX activity assay was performed in 96-well plates with an end point insulin assay $[39,40]$. We incubated $10 \mu \mathrm{g}$ TRX with $100 \mu \mathrm{g} /$ $\mathrm{ml}$ or $500 \mu \mathrm{g} / \mathrm{ml} \mathrm{SzP}$ at $37^{\circ} \mathrm{C}$ for $2 \mathrm{~h}$. Samples were mixed with $3.8 \mu \mathrm{l} 1.7 \mathrm{mM}$ TRX reductase from rat liver (Sigma), $20 \mu \mathrm{l}$ 1:12 mixture of solution $\mathrm{N}(40 \mathrm{mg} / \mathrm{ml} \beta-\mathrm{NADPH})$, solution $\mathrm{M}(210 \mathrm{mM}$ HEPES, pH 7.6, $790 \mu \mathrm{M}$ insulin, $20 \mathrm{mM}$ EDTA) and TE (50 mM Tris-HCl, pH 7.6, $20 \mathrm{mM}$ EDTA) to reach a total volume of $50 \mu \mathrm{l}$. The reaction mixture without TRX reductase was used as the control for background readings. After incubating in $37^{\circ} \mathrm{C}$ for

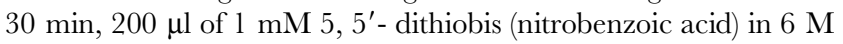
guanidine hydrochloride solution was added to stop the reaction and the absorbance was measured at $412 \mathrm{~nm}$.

\section{Recruitment of TRX to the surface of viable $S$. zooepidemicus}

The flow cytometry analysis of S. zooepidemicus ATCG 35246 cultured in vitro was performed as described previously [41].
Briefly, $5 \times 10^{7} \mathrm{CFU} / \mathrm{mL}$ wild strain or the $\mathrm{SzP}$ knockout was incubated for $30 \mathrm{~min}$ at $37^{\circ} \mathrm{C}$ in $2 \mathrm{mg} / \mathrm{mL}$ TRX. The bacteria cells were washed with phosphate-buffered saline (PBS; pH 7.2), collected by centrifugation, and incubated with rabbit anti-mouse TRX polyclonal antibodies (Proteintech, USA) for $30 \mathrm{~min}$ at $37^{\circ} \mathrm{C}$. This was followed by incubation with FITC-conjugated goat anti-rabbit IgG secondary antibodies (Beyotime, China). Surface-bound TRX was fluorescently stained and analyzed by a FACS Calibur (Becton Dickinson). Data were compared by the analysis of variance with Tukey's correction for multiple comparisons and Student's t-test. $\mathrm{P}$ values $<0.05$ were considered significant.

\section{Macrophage TRX knockdown and Phagocytosis assays}

siRNA templates were designed using online siRNA Target Finder (Ambion, Japan) to match 20 nonconserved nucleotide sequences within the mouse TRX mRNA. The oligo nucleotide sequences used to create pBAsi-mU6-TRX were iTRX-sense 5' - GATCGGGCTTGAAGCCTCTATTACTTTCAAGAGAAGTAATAGAGGGTTCAAGC TTTTTTACGCGTG - 3' $^{\prime}$ and iTRX-antisense 5' CACGCGTAAAAAAGGTTGAAGCGT CTATTACTTCTCTTGAAAGTAATAGAGGCTTCAAGCGG -3'. The oligonucleotides were annealed and cloned into pBAsi-mU6 (TAKARA Bio, Japan). The expression of TRX siRNA was regulated by the mU6 promoter. Cells were harvested $24 \mathrm{~h}$ and $36 \mathrm{~h}$ after pBAsi-mU6TRX transfection. The lysates were collected for western-blot analysis and total RNA was extracted to confirm TRX knockdown using RTPCR analysis.

The phagocytosis assay was performed using a previously described method with some modifications [42]. The $S$. zooepidemicus wild type strain was cultured to mid-exponential phase of growth (optical density of $0.35-0.45$ at $600 \mathrm{~nm}$ ), washed, and resuspended in Dulbecco's phosphate-buffered saline at $1.25 \times 10^{8} \mathrm{CFU} / \mathrm{ml}$. Bacteria cells were labeled with $5.0 \mu \mathrm{g} / \mathrm{ml}$ FITC (Sigma) for $20 \mathrm{~min}$ at $37^{\circ} \mathrm{C}$ and the unbound labels were removed by 2 washes in DPBS. Labeled $S$. zooepidemicus were resuspended in DMEM and chilled on ice. The Raw264.7 cells $\left(10^{6}\right)$ or TRX knock-down cells $\left(10^{6}\right)$ were combined with $10^{7} \mathrm{~S}$. zooepidemicus wild type or the $\mathrm{SzP}$ knock-out strain in a 96-well microtiter plate on ice. Samples were mixed gently with a pipette and rotated at $37^{\circ} \mathrm{C}$ for $60 \mathrm{~min}$. At the desired times, samples were placed on ice and analyzed by flow cytometry. Samples were analyzed to determine the total number of Raw264.7 cells with bound/ingested bacteria and then re-analyzed immediately in the presence of an equal volume of Trypan Blue $(2 \mathrm{mg} / \mathrm{ml}$ in $0.15 \mathrm{M}$ $\mathrm{NaCl} / 0.02 \mathrm{M}$ citrate buffer, $\mathrm{pH} 4.4)$ to measure the number of Raw264.7 cells with ingested bacteria (phagocytosis). A total of 10,000 events were collected per sample and a single gate was used to exclude debris and free bacteria (Cell Quest Pro Software, BD Biosciences). Phagocytosis percentage was determined by the percentage of FITC positive Raw264.7 cells after quenching with Trypan Blue.

\section{$\mathrm{FH}$ binding assay}

Binding of $\mathrm{SzP}$ and TRX to $\mathrm{FH}$ was determined using the method previously described with some modifications [43]. SzP, TRX and SzP/TRX complex were incubated at $37^{\circ} \mathrm{C}$ for $2 \mathrm{~h}$ before being subjected to SDS-PAGE and electro-transferred to a PVDF membrane. After blocking with $5 \%$ non-fat dry milk in TBST buffer, the membrane was incubated with fresh porcine 1:200 serum dilution followed by 1:8 goat anti-human FH serum dilution (Calbiochem, La Jolla, CA) in TBST. After washing in TBST, the blot was developed with HRP conjugated rabbit anti- 
goat IgG antibodies and followed by Chemiluminescence with SuperSignal ${ }^{\circledR}$ West Pico Substrate (Pierce, USA).

\section{C3 Convertase Measurement}

C3 convertase activity was measured as previously described with some modifications [44]. Briefly, the C3 convertase was assembled in PBS by the addition of the following purified complement components: $10 \mu \mathrm{g}$ C3 (Sigma); $50 \mathrm{ng}$ C3i; $2 \mu \mathrm{g}$ factor B (Calbiochem); and $12 \mu \mathrm{l} 0.1 \mathrm{M} \mathrm{MgCl}_{2}$. C3i, also known as $\mathrm{C} 3\left(\mathrm{H}_{2} \mathrm{O}\right)$, was generated by five freeze/thaw cycles of the purified C3. Varying concentrations of TRX, SzP, and the $\mathrm{SzP} /$ TRX complex were added with or without $10 \mu \mathrm{g} \mathrm{FH}$, followed by $200 \mathrm{ng}$ factor D (Calbiochem). The reaction mixture was incubated at $37^{\circ} \mathrm{C}$ for 30 minutes. The generation of C3a was measured by ELISA (Quidel, San Diego, CA). All experiments included positive controls (C3, C3i, factor B, and factor D) and negative controls (C3, C3i, and factor B).

\section{C3 binding assay}

The C3 deposition assay was performed using a previously reported protocol with some modifications [45]. Aliquots of $S$. zooepidemicus wild type and SzP-knockout strains $\left(1.5 \times 10^{8}\right.$ cells in $150 \mu \mathrm{l}$ of THB medium) were incubated with $10 \mu \mathrm{g}$ TRX, $10 \mu \mathrm{g}$ $\mathrm{FH}$ or $\mathrm{TRX}+\mathrm{FH}$ for $30 \mathrm{~min}$. Fresh porcine plasma $(180 \mu \mathrm{l})$ incubated at $37^{\circ} \mathrm{C}$ was then added and mixed with shaking. Complement deposition was stopped immediately after $30 \mathrm{~min}$ by the addition of $12 \mu \mathrm{l} 0.5 \mathrm{M}$ EDTA ( $\mathrm{pH} 8.0)$.

Flow cytometry analysis: The cells were spun down by centrifugation at $13,000 \mathrm{~g}$ for $2 \mathrm{~min}$. Cell pellets were washed

\section{References}

1. Eyre DW, J SK, Bowler IC, McBride SJ (2010) Streptococcus equi subspecies zooepidemicus meningitis-a case report and review of the literature. Eur J Clin Microbiol Infect Dis.

2. Abbott Y, Acke E, Khan S, Muldoon E, Markey B, et al. (2009) Zoonotic transmission of Streptococcus equi subsp. zooepidemicus from a $\operatorname{dog}$ to a handler. J Med Microbiol.

3. Hornef MW, Wick MJ, Rhen M, Normark S (2002) Bacterial strategies for overcoming host innate and adaptive immune responses. Nat Immunol 3: 1033-1040.

4. Ernst JD (2000) Bacterial inhibition of phagocytosis. Cell Microbiol 2: 379-386.

5. Wibawan IW, Pasaribu FH, Utama IH, Abdulmawjood A, Lammler C (1999) The role of hyaluronic acid capsular material of Streptococcus equi subsp. zooepidemicus in mediating adherence to HeLa cells and in resisting phagocytosis. Res Vet Sci 67: 131-135.

6. Campo RE, Schultz DR, Bisno AL (1995) M proteins of group G streptococci: mechanisms of resistance to phagocytosis. J Infect Dis 171: 601-606.

7. Bisno AL (1979) Alternate complement pathway activation by group A streptococci: role of M-protein. Infect Immun 26: 1172-1176.

8. Moore BO, Bryans JT (1969) Antigenic classification of group C animal streptococci. J Am Vet Med Assoc 155: 416-421.

9. Timoney JF, Walker J, Zhou M, Ding J (1995) Cloning and sequence analysis of a protective M-like protein gene from Streptococcus equi subsp. zooepidemicus. Infect Immun 63: 1440-1445

10. Hong-Jie F, Fu-yu T, Ying M, Cheng-ping L (2009) Virulence and antigenicity of the szp-gene deleted Streptococcus equi ssp. zooepidemicus mutant in mice. Vaccine 27: $56-61$.

11. Chae HZ, Robison K, Poole LB, Church G, Storz G, et al. (1994) Cloning and sequencing of thiol-specific antioxidant from mammalian brain: alkyl hydroperoxide reductase and thiol-specific antioxidant define a large family of antioxidant enzymes. Proc Natl Acad Sci U S A 91: 7017-7021.

12. Nakamura H (2008) Extracellular functions of thioredoxin. Novartis Found Symp 291: 184-192; discussion 192-185, 221-184.

13. Kondo N, Ishii Y, Kwon YW, Tanito M, Horita H, et al. (2004) Redox-sensing release of human thioredoxin from $\mathrm{T}$ lymphocytes with negative feedback loops. J Immunol 172: 442-448.

14. Jarva H, Jokiranta TS, Wurzner R, Meri S (2003) Complement resistance mechanisms of streptococci. Mol Immunol 40: 95-107.

15. Rautemaa R, Meri S (1999) Complement-resistance mechanisms of bacteria. Microbes Infect 1: 785-794.

16. Rodriguez de Cordoba S, Esparza-Gordillo J, Goicoechea de Jorge E, LopezTrascasa M, Sanchez-Corral P (2004) The human complement factor $\mathrm{H}$ : functional roles, genetic variations and disease associations. Mol Immunol 41: 355-367. twice and resuspended in PBS. Surface-bound C3b was detected with anti-C3 antibodies (Sigma) and FITC-labeled goat anti-rabbit IgG (Beyotime). The binding of the antibodies was measured by flow cytometry. A total of 10,000 events were collected per sample and a single gate was used to exclude debris (Cell Quest Pro Software, BD Biosciences).

Western-blot analysis: the cells were spun down and resuspended in $80 \mu \mathrm{l} 1 \mathrm{M}$ hydroxylamine in carbonate buffer $(\mathrm{pH} 9.0)$ after washing with PBS-1\% SDS twice. The mixture was incubated at $37^{\circ} \mathrm{C}$ for $1 \mathrm{~h}$ with gentle shaking. After centrifugation, aliquots $(25 \mu \mathrm{l})$ of the supernatant were subjected to SDSPAGE and transferred to a PVDF membrane. The membrane was incubated with a 1:100 dilution of anti-C3 antibodies (Sigma), and developed using HRP conjugated goat anti- rabbit IgG antibodies (Beyotime, China). The bands were visualized by Chemiluminescence with SuperSignal ${ }^{\circledR}$ West Pico Substrate (Pierce, USA).

\section{Statistical analysis}

All statistics were performed using an unpaired two-tailed $t$-test with a $95 \%$ confidence interval. In all experiments, error bars were denoted using the standard deviation $( \pm \mathrm{SD})$ of the samples in triplicates or more.

\section{Author Contributions}

Conceived and designed the experiments: ZM HF CL. Performed the experiments: ZM HZ JZ YL. Analyzed the data: ZM HF. Contributed reagents/materials/analysis tools: ZM LY. Wrote the paper: ZM HF.

17. Carlsson F, Berggard K, Stalhammar-Carlemalm M, Lindahl G (2003) Evasion of phagocytosis through cooperation between two ligand-binding regions in Streptococcus pyogenes M protein. J Exp Med 198: 1057-1068.

18. Staali L, Morgelin M, Bjorck L, Tapper H (2003) Streptococcus pyogenes expressing $\mathrm{M}$ and M-like surface proteins are phagocytosed but survive inside human neutrophils. Cell Microbiol 5: 253-265.

19. Inomata Y, Tanihara H, Tanito M, Okuyama H, Hoshino Y, et al. (2008) Suppression of choroidal neovascularization by thioredoxin-1 via interaction with complement factor H. Invest Ophthalmol Vis Sci 49: 5118-5125.

20. Billiet L, Furman C, Larigauderie G, Copin C, Brand K, et al. (2005) Extracellular human thioredoxin-1 inhibits lipopolysaccharide-induced interleukin-1beta expression in human monocyte-derived macrophages. J Biol Chem 280: 40310-40318.

21. Junn E, Han SH, Im JY, Yang Y, Cho EW, et al. (2000) Vitamin D3 upregulated protein 1 mediates oxidative stress via suppressing the thioredoxin function. J Immunol 164: 6287-6295.

22. Timoney JF, Artiushin SC, Boschwitz JS (1997) Comparison of the sequences and functions of Streptococcus equi M-like proteins SeM and SzPSe. Infect Immun 65: 3600-3605.

23. Bruckner A, Polge C, Lentze N, Auerbach D, Schlattner U (2009) Yeast twohybrid, a powerful tool for systems biology. Int J Mol Sci 10: 2763-2788.

24. Andersen JF, Sanders DA, Gasdaska JR, Weichsel A, Powis G, et al. (1997) Human thioredoxin homodimers: regulation by $\mathrm{pH}$, role of aspartate 60 , and crystal structure of the aspartate $60 \rightarrow$ asparagine mutant. Biochemistry 36 : 13979-13988.

25. Weichsel A, Gasdaska JR, Powis G, Montfort WR (1996) Crystal structures of reduced, oxidized, and mutated human thioredoxins: evidence for a regulatory homodimer. Structure 4: 735-751.

26. Heath DG, Cleary PP (1989) Fc-receptor and M-protein genes of group A streptococci are products of gene duplication. Proc Natl Acad Sci U S A 86: $4741-4745$.

27. Johnsson E, Thern A, Dahlback B, Heden LO, Wikstrom M, et al. (1996) A highly variable region in members of the streptococcal $\mathrm{M}$ protein family binds the human complement regulator C4BP. J Immunol 157: 3021-3029.

28. Kantor FS (1965) Fibrinogen Precipitation by Streptococcal M Protein. I. Identity of the Reactants, and Stoichiometry of the Reaction. J Exp Med 121: 849-859.

29. Horstmann RD, Sievertsen HJ, Knobloch J, Fischetti VA (1988) Antiphagocytic activity of streptococcal $\mathrm{M}$ protein: selective binding of complement control protein factor H. Proc Natl Acad Sci U S A 85: 1657-1661.

30. Joiner KA (1988) Complement evasion by bacteria and parasites. Annu Rev Microbiol 42: 201-230. 
31. Wessels MR, Moses AE, Goldberg JB, DiCesare TJ (1991) Hyaluronic acid capsule is a virulence factor for mucoid group A streptococci. Proc Natl Acad Sci U S A 88: 8317-8321.

32. Bartelt MA, Duncan JL (1978) Adherence of group A streptococci to human epithelial cells. Infect Immun 20: 200-208.

33. Holden MT, Heather Z, Paillot R, Steward KF, Webb K, et al. (2009) Genomic evidence for the evolution of Streptococcus equi: host restriction, increased virulence, and genetic exchange with human pathogens. PLoS Pathog 5: e1000346.

34. Gietz RD, Woods RA (2006) Yeast transformation by the LiAc/SS Carrier DNA/PEG method. Methods Mol Biol 313: 107-120.

35. Stagljar I, Korostensky C, Johnsson N, te Heesen S (1998) A genetic system based on split-ubiquitin for the analysis of interactions between membrane proteins in vivo. Proc Natl Acad Sci U S A 95: 5187-5192.

36. Johnsson N, Varshavsky A (1994) Split ubiquitin as a sensor of protein interactions in vivo. Proc Natl Acad Sci U S A 91: 10340-10344.

37. Nishiyama A, Matsui M, Iwata S, Hirota K, Masutani H, et al. (1999) Identification of thioredoxin-binding protein-2/vitamin $\mathrm{D}(3)$ up-regulated protein 1 as a negative regulator of thioredoxin function and expression. $\mathrm{J}$ Biol Chem 274: 21645-21650.
38. Fan H, Wang Y, Tang F, Lu C (2008) Determination of the mimic epitope of the M-like protein adhesin in swine Streptococcus equi subsp. zooepidemicus. BMC Microbiol 8: 170.

39. Arner ES, Zhong L, Holmgren A (1999) Preparation and assay of mammalian thioredoxin and thioredoxin reductase. Methods Enzymol 300: 226-239.

40. Luthman M, Holmgren A (1982) Rat liver thioredoxin and thioredoxin reductase: purification and characterization. Biochemistry 21: 6628-6633.

41. Dave S, Brooks-Walter A, Pangburn MK, McDaniel LS (2001) PspC, a pneumococcal surface protein, binds human factor H. Infect Immun 69: 3435-3437.

42. Hoe NP, Ireland RM, DeLeo FR, Gowen BB, Dorward DW, et al. (2002) Insight into the molecular basis of pathogen abundance: group A Streptococcus inhibitor of complement inhibits bacterial adherence and internalization into human cells. Proc Natl Acad Sci U S A 99: 7646-7651.

43. Campbell JR, Baker CJ, Edwards MS (1991) Deposition and degradation of C3 on type III group B streptococci. Infect Immun 59: 1978-1983.

44. McRae JL, Duthy TG, Griggs KM, Ormsby RJ, Cowan PJ, et al. (2005) Human factor H-related protein 5 has cofactor activity, inhibits C3 convertase activity, binds heparin and C-reactive protein, and associates with lipoprotein. J Immunol 174: $6250-6256$

45. Tiwari R, Qin A, Artiushin S, Timoney JF (2007) Se18.9, an anti-phagocytic factor H binding protein of Streptococcus equi. Vet Microbiol 121: 105-115. 